\title{
Open Educational Resources as a Tool to Improve Language Education Effectiveness in the Russian Higher Education Institutions
}

\author{
http://dx.doi.org/10.3991/ijet.v9i5.3962 \\ T.V. Sidorenko \\ National Research Tomsk Polytechnic University, Tomsk, Russia
}

\begin{abstract}
An attempt of Russian universities to move forward to the leading positions in the world rankings has resulted in some initiatives to enhance their activities on the market of education services. Under these conditions, foreign language proficiency is no longer a luxury and it is becoming an important tool to implement goals of university development. In this regard, new methods and techniques of foreign language teaching are highly demanded, which would significantly improve the language competency of both students and faculty members. A search for effective methods to enhance foreign language teaching makes analyze Massive Open Online Courses (MOOCs) open educational platforms and consider an opportunity for these platforms to be integrated into the existing system of foreign language teaching in Russian higher education institutions. Based on the research findings, the author concludes that it is irrational to use the resources as embedded components without significant adjustment to the conditions existing in the current higher education system.
\end{abstract}

Index Terms - language education, language competency, MOOCs, open educational platforms, traditional education format.

Nowadays, one of the relevant objectives the Russian universities are facing is to enhance Russian higher education (HE) which is associated with recognition by the global university society and increasing competitiveness of the Russian universities on the world education market.

The HE in Russia strives primarily for entering the world's university rankings where the most significant indicators are academic reputation, employer's assessment, the number of foreign specialists involved, percentage of international students, citation index, and proportion of faculty members to students [1].

It should be admitted that achievement of high indicators is quite a difficult objective for the leading Russian universities, which is explained by some reasons: 1) poor integration of the higher education system into the world academic community, 2) poor cooperation of scientific schools with the world's leading research centers. Historical isolation of the country generated one more reason 3 ) a low level of foreign language proficiency.

Language competency in the Tomsk Polytechnic University's roadmap is considered as one of the viable tools to fulfill some key indicators. Foreign language proficiency on level Bland above (according to the Common European Framework of Reference for Languages [2]) for students, $\mathrm{PhD}$ candidates and university staff is reported in the roadmap as a "fast victory". However, this statement might be partly true due to the time factor.

The University is facing an objective: how to train a large number of students and faculty members to be able to use a foreign language in their professional activity without increasing the number of foreign language instructors [3].

In this regard, it has become relevant to search for the ways how to optimize foreign language teaching under conditions of the current system of higher education. The administration of Tomsk Polytechnic University (TPU) has determined three priority activities to:

- involve native speakers to teach classes in foreign language;

- create bilingual environment for social interaction;

- develop innovative technologies for foreign language teaching using open electronic educational resources such as MOOCs [4].

Farther, let us consider the implementation mechanisms of the last point listed above. The task here is to examine opportunities of open educational platforms in order to integrate them as a variable or built-in component into the entire course of foreign language teaching provided that: 1) the number of foreign language instructors does not go beyond the limit, and 2) the quality of knowledge and experience of students are improved.

Let us specify changeable and unchangeable conditions. The unchangeable conditions include: line schedule, curriculum, number of academic hours (classroom and nonclassroom hours), education goals and outcomes in compliance with the Principal Education Program (PEP) [5]. For the changeable conditions, let us specify: study materials, didactic tools, education format (classroom/online work), the system of management and cooperation between participants of the education process.

As a set of learning outcomes for a foreign language course, it is determined to (Table 1): 
TABLE I.

LEARNING OUTCOMES OF A COURSE "FOREIGN LANGUAGE"

\begin{tabular}{|l|l|}
\hline $\begin{array}{c}\text { Learning } \\
\text { outcome } \\
\text { (LO) Code }\end{array}$ & \multicolumn{1}{c|}{$\begin{array}{c}\text { Learning outcomes of an academic course } \\
\text { (a graduate shall be ready to) }\end{array}$} \\
\hline LO 1 & $\begin{array}{l}\text { Find, extract, analyze, interpret, and represent } \\
\text { significant professional information in a foreign } \\
\text { language in oral or written form. }\end{array}$ \\
\hline LO 2 & $\begin{array}{l}\text { Master spoken language to be able to handle social } \\
\text { and communicative tasks in typical situations of } \\
\text { professional field and academic environment as well } \\
\text { as to present research findings and take part in } \\
\text { scientific conferences in a foreign language. }\end{array}$ \\
\hline LO 3 & $\begin{array}{l}\text { Master written language to be able to present re- } \\
\text { search findings and write research papers, theses, } \\
\text { abstracts, and synopses in a foreign language. }\end{array}$ \\
\hline LO 4 & $\begin{array}{l}\text { Cooperate with representatives of different cultures } \\
\text { in carrying out professional activities in a foreign } \\
\text { language, be able to understand and overcome cross- } \\
\text { cultural differences, be tolerant and take responsibil- } \\
\text { ity to support and develop partnership and trustful } \\
\text { relationship. }\end{array}$ \\
\hline LO 5 & $\begin{array}{l}\text { Use foreign language knowledge to plan and im- } \\
\text { plement strategic directions of intellectual, cultural } \\
\text { moral , and professional self-development, self- } \\
\text { education and self-improvement }\end{array}$ \\
\hline $\begin{array}{l}\text { Work in a team to perform projects in a foreign } \\
\text { language and demonstrate willingness to cooperate } \\
\text { with other team members }\end{array}$ \\
\hline
\end{tabular}

The analysis of didactic opportunities for the open educational platform courses is based on the assumption that integration of MOOCs as a variable component of teaching into the programs of foreign language training of technical university students will provide for improving learning outcomes within a short period of time without increasing the number of foreign language instructors.

Learning outcomes given in Table 1 will be considered as outcome criteria. The compliance of MOOCs courses with these criteria will be checked. For a start, the educational platforms under study will be briefly characterized.

What are MOOCs? These are massive open online courses. Their basic principle of functioning is to make higher education accessible. According to the standards of electronic education, MOOC courses use quite a simple teaching model: short lectures (10-15 minutes), tests with automatic checking, materials recommended for self-study work [6].

The basic didactic principle of MOOCs is a high level of interaction between listeners provided by the discussion of lecture materials as well as cross-evaluation and participation in forums. A necessary condition of interaction is a good knowledge of a foreign language [7].

Anecdotal evidence of academic university community states that MOOC's inventors have opened Pandora's Box. The scope of MOOCs' development and popularity raises questions about the existing educational system and the mere existence of universities as a social institute. It is argued that under successful functioning and development of MOOCs, students will be able to "collect" their qualification on their own, based on the educational courses available at the world's leading universities [8].

As of today, one of the controversial issues is that the knowledge gained by students is confirmed by means of certificate. The platforms issue certificates such as "statement of completion", which certify completion of the course and do not provide any information about the level to define student's knowledge. Platform holders do not have official agreements with universities to grant MOOCs academic credits. Universities, in their turn, do not rush to do that [9].

However, this opportunity might be realistic in the future. Open platforms, which are becoming popular as a flexible and accessible form of education, can bring about some kind of "technical revolution" in higher education. Acknowledgement of MOOCs' qualification will suggest for significant personnel cuts in traditional universities, management revision, and the necessity of university functioning per se might become an issue to be solved in the future. So far, it is too early to discuss a fundamental impact of MOOCs, which is proved by a significant drawback - MOOCs demonstrate high percent of unfinished education, only $9 \%$ of users complete the programs [8].

At first glance, everything looks perfect: MOOCs' education format corresponds to the didactic goal; education environment is clear and acceptable. However, if MOOCs are considered as a component to be integrated into the existing system, then it raises a question: whether the management tools of this system are capable of adapting a new component under their requirements and conditions.

As mentioned above, any system has changeable and unchangeable conditions. Traditionally, the beginning of academic courses in Russian universities is determined by the beginning of a semester, whereas the number of academic hours is determined by a curriculum of an educational program. Even if we consider the case when a part of the traditional course is replaced by a MOOC, which can be integrated as a variable component, we cannot ignore the functioning conditions of the entire system.

It should be noticed that MOOCs' curricular do not provide for a long-term planning. Open platforms do not function in a cyclic mode. Courses can be offered either every 3-6 months or only once. Thus, a holistic approach to a curriculum planning in a traditional way is not appropriate. It is possible only if universities are ready to make annual renewal of the content of their academic courses and to change line schedules. However, it is a laborconsuming process.

Platforms can partially provide conditions to develop communication skills, by means of participating in forums. A forum assumes that opinions are changed in a free format. The basic goal is to provide cross-studying and assessment focused on expanding professional knowledge and developing skills for critical analysis.

It is important that an enormous number of people and representatives of various cultures and languages take part in discussions. As a result, students become motivated and they feel being involved in global discussion of professional issues which helps to eliminate language barriers, provides conditions for language immersion and smoothes cultural differences.

However, communication in forums is done in writing only, with the lack of speaking. At the same time, forum is a type of computer-mediated communication which is not perceived as a written discourse. It does not establish high-level requirements for "language quality"; it allows to use not only lexical but punctuation neologisms. Slang and professional jargon are accepted as communication tools that everyone understands. The following examples can prove it. Resource - Coursera. Course - Model of thinking by Scott E. Page. 
Sample 1 (introducing yourself): "I'm 26 years old, from Ukraine (have anyone ever heard about it), have no technical education, but master's degree in international economic and interpreting. I'm here due to my decision to learn more about database and the stuff. Hope this course in modelling will help me to expand my area of thought. So let's look how far I can get.

Sample 2 (discussing a case): in the first exercise of take decision by criteria of House 1 and House 2. We could use for each criteria a \%? I said this coz maybe for some people its more important one Ctriteria than others. Its possible to do?

Thus, a forum can hardly be seen as a ground to develop language skills. It can be partially viewed as a condition for language immersion environment since it functions according to its own rules. Consequently, students can master communication skills only within these rules. The question here is: is it enough for future professionals? In the future, will engineer specialists communicate only in forums?

MOOCs lack oral communication, which is possible to provide within classroom training using a blended method of teaching. However, in this case the content of the main subject must be closely integrated with the content of MOOCs. But taking into account that an instructor cannot be aware of the content of MOOCs learning materials in advance, he/she will have to organize "just-in-time" training. In this case, it brings up the question "how to comply with the principals of systematic and consecutive teaching, quality of teaching and university willingness to implement the model of quick responsiveness?"

One of the most contradictory issues in considering a chance of integrating, so called, "ready to use" educational products into the existing system is how to manage the process of education. Management can be tentatively divided into two components: 1) who manages the process, and 2) tools to manage the process [10]. An attempt to answer the first question leads to deadlock. First, if the process is managed by language instructors, then they do not have specific knowledge to analyze the content in order to facilitate professional discussions. If professional faculty members are involved in management, then the question here is whether they are ready to give a professional course in a foreign language.

Even if we take into account an opportunity for implementing both scenarios, then it saves the situation only partially since for monitoring and developing training technologies, the instructor will be required to register for the course as a participant and to study the course along with the students in order to follow up student's performance. Additionally, the instructor will have to include course materials of the open platforms into his testing packages or materials. Thus, mastering the logic of materials that were developed by someone, adapting them to communication format, developing new mechanisms of assessment - all these will require labor inputs, however, quality and progress will not be assured.

The SWOT analysis is used here to show intermediate conclusions. Then, a final evaluation of the resources used under study in foreign language teaching is provided.

\section{Strengths:}

1. High quality content;

2. High technological support;

3. Integration of language environment;

4. Expanding the limits of teaching due to distance learning technologies;

5. Expanding professional and terminological vocabulary in a foreign language.

\section{Opportunities:}

1. Receiving new knowledge from the world's leading universities;

2. Global communication;

3. Smoothing language and cultural barriers;

4. Positive impact on university reputation allows "to be in trend", attracting new undergraduate applicants;

5. Flexible format of learning, development of skills to manage academic freedom.

The conclusions reached are taken as a basis for potential assessment of MOOCs to achieve the learning outcomes expected for the academic course as "Foreign Language" (Table II).

According to estimation, the average percent of effectiveness in foreign language teaching is $25 \%$. On condition that some difficulties occur in order to adapt the management system of open platforms to the existing university studying system, it should be noted that the research assumption has been proven false. MOOCs can be considered as independent, autonomous and effective resources for self-study which encourage development of professional and linguistic competency. We admit that foreign language instructors can use platform resources as additional materials to educational programs in teaching a foreign language and/or in teaching a special course via a foreign language. 
TABLE II.

OPPORTUNITIES TO REACH LEARNING OUTCOMES

\begin{tabular}{|c|c|c|}
\hline $\begin{array}{l}\text { Learning } \\
\text { outcomes } \\
\text { Code }\end{array}$ & $\begin{array}{l}\text { Learning outcomes of an } \\
\text { academic course } \\
\text { (a graduate shall be ready to) }\end{array}$ & $\begin{array}{l}\text { Performance } \\
\text { opportunities (in } \\
\text { case MOOCs are } \\
\text { integrated as a } \\
\text { variable component } \\
\text { of the course) } \\
\end{array}$ \\
\hline \multirow{2}{*}{ LO 1} & $\begin{array}{l}\text { Find, extract, analyze, and interpret } \\
\text { significant professional information; }\end{array}$ & $60 \%$ \\
\hline & $\begin{array}{l}\text { Transfer information in oral and } \\
\text { written forms in a foreign language. }\end{array}$ & $0 \%, 20 \%$ \\
\hline \multirow[t]{2}{*}{ LO 2} & $\begin{array}{l}\text { Be able to speak a foreign language to } \\
\text { solve social and communication } \\
\text { problems in typical situations of } \\
\text { professional area and academic envi- } \\
\text { ronment. }\end{array}$ & $5 \%$ \\
\hline & $\begin{array}{l}\text { Be able to present research findings, } \\
\text { participate in scientific conferences. }\end{array}$ & $10 \%$ \\
\hline LO 3 & $\begin{array}{l}\text { Be able to write in a foreign language } \\
\text { to document research findings and } \\
\text { write scientific articles, theses, ab- } \\
\text { stracts, and synopses in a foreign } \\
\text { language. }\end{array}$ & $5 \%$ \\
\hline \multirow[t]{2}{*}{ LO 4} & $\begin{array}{l}\text { Cooperate with representatives of } \\
\text { different cultures in carrying out } \\
\text { professional activities in a foreign } \\
\text { language, be able to understand and } \\
\text { overcome cross-cultural differences, } \\
\text { and be tolerant. }\end{array}$ & $20 \%$ \\
\hline & $\begin{array}{l}\text { Take responsibility to support and } \\
\text { develop partnership and trustful rela- } \\
\text { tionship. }\end{array}$ & $0 \%$ \\
\hline LO 5 & $\begin{array}{l}\text { Use foreign language knowledge to } \\
\text { plan and implement strategic direc- } \\
\text { tions of intellectual, cultural, moral, } \\
\text { and professional self-development, } \\
\text { self-education and self-improvement. }\end{array}$ & $50 \%$ \\
\hline LO 6 & $\begin{array}{l}\text { Work in a team in performing projects } \\
\text { in a foreign language and demonstrate } \\
\text { willingness to cooperate with other } \\
\text { team members. }\end{array}$ & $0 \%$ \\
\hline
\end{tabular}

It is obvious that opportunity assessment in percentage is subjective. The assessment was based on a survey of 20 foreign language instructors.

\section{REFERENCES}

[1] University Rankings // Edited by L. Taradina // Academic community. National research university Higher school of economics. - 2012. - 9 (14). - [electronic resource]. - Retrieved from: http://www.hse.ru/data/2012/11/23/1301711586/Area_14.pdf (09.03.2014).

[2] Common European Framework of Reference for Languages: Learning, Teaching, Assessment. (2001). Cambridge University Press. P. 260.

[3] Tomlinson B., Whittaker C. (2013). Blended Learning in English Teaching: Course, Design and Implementation. London. P. 12-14.

[4] A Program for Enhancing Competitiveness of the National Research Tomsk Polytechnic University. Retrieved from http://tpu.ru/today/programs/viu (10.01.14).

[5] A Basic Work Program of the Unified Module for the Course of Professional Foreign Language. Retrieved from:

http://portal.tpu.ru:7777/departments/kafedra/iyaik/study\%20orga nization/ (28.04.2014).

[6] Massive Open Online Courses. Retrieved from: http://wikipedia.org/wiki/Massive_open_online_course/ (20.04.2014).

[7] Belyayeva E.A. MOOCs and the Future of Higher Education. Retrieved from: http://www.syktu.ru/2013/04/25/MOOCS (10.02.2014).

[8] Dhawal S. MOOCs in 2013: Breaking down the Numbers. Retrieved from: http://www.edsurge.com/n/2013-12-22-moocs-in2013-breaking-down-the-numbers (29.04.2014).

[9] The Maturing of the MOOC. Department of Business Innovation and Skills. Literature Review of Massive Open Online Courses and other Forms of Distance Learning. Research paper number 130. Sep.2013. London. 123 p. URL: www.gov.uk/bis

[10] Popov P.P., Cherkasova I.I. (2013). Opportunities of Distance Educational Technologies Based on MOODLE, ADOBE CONNECT, MOOCS in the Development of Innovative Thinking of Subjects in Educational Environment // Contemporary Issues of Science and Education. Retrieved from: www.scienceeducation.ru/109-9268 (29.04.2014).

\section{AUTHOR}

T. V. Sidorenko is with the National Research Tomsk Polytechnic University, Tomsk, Russia (e-mail: sidorenkot@tpu.ru).

Submitted 14 June 2014. Published as resubmitted by the author 19 August 2014. 